\title{
Criminal Profiling in Homicide Offenses
}

\author{
Petronela Diana Ferariu \\ “Alexandru Ioan Cuza” University of Iași, Faculty of Law, Romania, dianaferariu@gmail.com \\ Company EuroAsia of Iași, Romania
}

\begin{abstract}
The behavioral investigation of homicide crimes involves a thorough activity to identify the psychological trail left by the author at the crime scene, during committing the deed. This research method provides details of the typology of the person who committed the murder offense and reduces the number of suspects. Identifying the traits of the psychological profile of the killer is particularly effective and can prove itself valuable in investigating homicides with unknown authors, especially in those involving various forms of psychopathology, expressed through mutilation, multiple postmortem stabbing, sadism, evisceration, ritual crimes, burning of the corpse and so forth. The scientific progress of society, through its strongest propulsion power, respectively the technological development, provides a source of information for many offenders by suggest alternatives to alter the crime scene, so that the traces of the act are altered or even lost. This aspect is one of the reasons why the profiler should carefully analyze and investigate the scene of the crime in order to discover and fix all traces and subsequently to be able to reproduce the events scene as accurately as possible. Psychological profiling is an important component of forensic research, given its role in the reconstitution of the crime scene, the discovery, fixation and interpretation to traces and, last but not least, the identification of the perpetrator. The research highlights the need to have a clear view of homicides, in a national context and the general objective is to highlight the characteristics of the murders committed by Romanian perpetrators.
\end{abstract}

KEYWORDS: crime scene, criminal profiling, forensic, homicide, investigation, Romanian perpetrators, traces

\section{Introduction}

In the investigation of crimes, regarding especially to homicide, the psychological analysis of criminal behavior and profiling is increasingly used globally. Over time, the Romanian judicial practice has faced a large number of complex cases, which have presented different modes of operation, sometimes specific, with a bizarre motivation to commit murder, with multiple victims or authors who have committed more homicide, where behavioral analysis could be realized and useful to investigators during the investigation, to decipher and understand how the person who committed the crime thought and acted, reason why harmonization of the Romanian legislation with the UE Member States in terms of behavioral analysis has become more than necessary. In order to increase performance, Romanian legislation has been amended to align with European legislation and was approved by issuing the Order by Ministry of Internal Affairs number I/2507 from $27^{\text {th }}$ of January 2014 and the legislative provision of the General Inspectorate of Romanian Police the establishment of the Behavioral Analysis Service at the level of the Criminal Investigation Division where sociologists, psychologists and criminal investigation officers are working in the investigation offenses of great violence, homicide and sexual assault. Thus, in Romania criminal investigation from the point of view of the behavioral analysis is legally regulated by Law no. from $19^{\text {th }}$ of July 2013.

\section{Homicide Investigation}

The result of the author's criminal profile in the case of homicide crime is not his name or robot portrait, but rather a kind of psychological footprint of the perpetrator describing his personality. This description provides information about the crime author, regarding age, gender, ethnicity, physical features such as birth marks or signs, weight, height, professional training, marital status, behavioral disorders, possible speech defects or difficulties in dealing with other people, and so forth (Butoi T., Butoi I., and Butoi A. 2011, 32). Profiling ratings are used in two distinct stages of the criminal process, namely in the criminal investigation phase and in the trial phase. In the criminal investigation phase, the main purpose of profiling is to reduce the number of suspects, to provide support in establishing the links that may exist with committing other antisocial crimes, and to provide authorities with viable strategies in conducting investigations. In the trial phase, the court may be helped to understand and better clarify the causes that have led to criminal behavior. 
In case of murder, the author's personality analysis and psychological features suggests how to identify the criminal's general profile aspects, as anatomical, psychological, sociological, physiological, cultural, economic, and so forth., which all of them may indicate and lead into committing homicide (Raine 2014, 143). Individuals whom commit crimes of great violence, often present a great deal of behavioral diversity and are part of a particular social category. Everyone committing a homicide crime is a particular case and presents a series of social attitudes, psychological and physiological characteristics that are not to be found specific to all offenders, although the reason for proposing a typology to people committing murder is difficult. The reason and purpose of committing murder followed by the author's internal impulse which triggers the criminal act are different from person to person and may be multiple, and also, the psychological mechanism that contributes to the decision to act needs to be analysis and understood very well as this is one of the basic conditions in the killer's psychological profile (Raine 2014, 143).

Crimes against individuals represent almost one third of the criminal phenomenon in Romania, in the following order by frequency: physical injuries, homicides, threats, false imprisonment and blackmailing. In the case of homicide crimes, it is noticeable that they predominate in urban areas, and the causes that lead to the victims of these crimes are various, such as murder for reckoning, murder for the purpose of purchasing money or valuables, murder of alcoholism, dementia, passion or sexual intercourse, racial causes, and so forth. A particularly important aspect in the fight against crime as a social phenomenon is the analysis of the crime as an individual factor, aiming mainly at identifying the facts that determine and tends into committing homicides (Turvey 2011, 302). The offender's behavior should be thoroughly analyzed, paying attention to the psychological determinations and external factors that cause his actions, in order to indicate the impulses that generate his negative manifestations and to choose the most efficient means of reeducation (Lăpăduşi and Iancu, 2004, 57).

The murderer manifests discontinuity in his behavior, change in mood, inconsistency and unpredictability in reactions to external stimuli. At the same time, it has difficulty in approaching or complying with the social requirements expressed by legal rules that need a certain conduct. A murderer is inappropriate, rejects any organized social and educational influences, is difficult to adapt, creating many problems in the social groups of belonging. In family relationships, they have little preoccupation in properly education of their children because of their low cultural and material levels, chronic alcoholism, labor shortages and criminal activities. This lack of concern in educating their own children is automatically taken over from the model of the family in which the murderer has grown, a model of a disorganized family, low affection towards the child, poor education and training, sometimes even infant psychological trauma (Tandin, Ștefan and Țupulan 2014, 237).

The criminal personality profile is a scientific conclusion that provides to authorities information about the type of person who could have committed the homicide. This involves preparing a biographical sketch based on crime scene information and victim particularities, then integrating psychological theories (Cartwright 2010, 211). The psychological analysis of the crime, consists in investigating the way in which the offender, through his/her wisdom, affectivity, motivation and will, manifests himself/herself in preparing, committing and attitude towards the committed act (Yablonsky 1990, 87).

Regarding the psychological evidence, everything is reduced to the behavior of the person committing the murder, to his/her way of acting and expelling, the psychologist being called to interpret and reconstruct these manifestations by assigning a certain meaning to the fragments of information present at the crime scene. A behavior similar to the one from the time of committing the crime may be similar to the whole of the daily manifestation of some subjects, but in other situations this behavior may change significantly. In Romania, violent crimes imply, perhaps the most, the dynamic side of human behavior. From the author's point of view, this behavioral particularity that leads to the manifestation of violence is normal, thus feeding its inner needs of a conflictual nature at an unconscious level, where for the specialist, the crime scene will contain clues of certain behavioral manifestations that will illustrate those criminal needs (Paraschiv G., Paraschiv D., and Paraschiv E. 2014, 73). 
After the detailed analysis of personal characteristics and criminal behavior, two portraits or general profiles were drawn, namely the typology of the organized criminal and the typology of the disorganized criminal. Thorough planning of crime is the feature that radically distinguishes the organized criminal by the disorganized one. The murderer who fits in this typology has a good intelligence, above average, good communication skills so he is capable of thorough crime planning. In the case of organized homicide crime, the victim is often a known person. To hinder his capture, the murderer tries not to leave traces of criminal activity, by transporting the body to another place, hiding the murder weapon and deleting the traces from the crime scene (Ionescu 1997, 60). From the outside, this type of killer carries that "mask of mental health" related to a psychopath: he seems to be a good guy, he is perfectly adapted, usually having a good job and a normal family, he is appreciated by his friends, colleagues and neighbors.

The disorganized criminal is the opposite of the one organized, and what makes it labeled as unorganized, is that it usually commits impulsive crimes, unpremeditated crimes, and is often a person with mental disorders of psychotic intensity. This type of criminal often disfigure their victim by applying excessive hits or by mutilation of the corpse. Impelled by impulsivity, the author of the homicide crime, acts quickly, extremely violently and attacks the victim by surprise. The murder is usually committed to known persons and the method of action is brutal, without preparatory acts, using objects nearby. The offender disappears from the scene, leaving more evidence like the body being left at the crime scene, or hiding it in a hurry or superficially.

As a response to the precise needs of investigating cases involving homicide crimes, psychological profiling has three main objectives, namely to provide a psychological and social assessment of the potential murderer. The profile will include the key elements in the identification process: age, religion, profession, marital status, education, habits, hobbies, and so forth. This will reduce the area of investigation, which will directly influence the total resources allocated including the duration of the settlement. Future attacks can be anticipated, both in terms of the act type and the possible location. The second objective is to indicate the types of objects the offender possesses. At the suspect's home, searches can be targeted on different objects categories: "Trophy objects" acquired after committing the murderer: magazines, literature, which serve to remembrance, "reliving" the violent episode. The third objective is to target tracking and interrogation strategies. In the case of the disorganized criminal typology, it is recommended: empathizing, counseling and indirect presentation of evidence. For organized criminals, is indicated a direct strategy, questioning and a firm attitude.

The crime scene investigation seeks to identify the existence of signs of struggle between the victim and the perpetrator. Blood stain analysis is considered one of the best ways to reconstruct the course of events. Along with this, the presence of plucked hair, moving or tearing down pieces of furniture, injuries, complements the investigative picture, and can support the hypothesis that there has been an altercation (Mitrofan, Zdrenghea and Butoi 1992, 53). Compared to inside homicides, open-space killings are not so easy to investigate. In the case of homicide committed in open space, signs of fighting can be identified, the soil is shattered and there are distinct footprints in different position to each other, indicating a fight between the two persons and the victim may have injures caused by self-defense.

Identifying of the murder weapon represents a priority of the investigators and judicial practice in our country confirms that the absence of the weapon defines a murder. Respecting existing national requirements for on-site research, if the murder weapon is at the scene of the crime, it is first observed by legal authorities, photographed and picked up to be analyzed. Examination of the corpse at the crime scene is done with caution, and any suspect positioning or any unnatural repositioning that would indicate a scenario should be observed, photographed, and measured. Behavioral analysis of the crime scene involves distinguishing the psychological evidence left by the author along the criminal act, recognizing the criminal characteristic and differentiating the behavior of the author from that of the victim (Cretu 2010, 112).

Starting from this principle, it is ensured the fidelity of interpretations associated with certain behavior and, on the other hand, directing the investigation into a certain type of offender. In order to 
achieve the criminal profile in the investigation of great violence murders, the following are significant: the purpose of the crime, the reason for choosing the place of deed, the risk associated with entering and leaving the criminal field, the characteristics of the victim, the particularities of the behavior traces present at the crime scene, the mode of operation and the criminal signature (Budăi and Gavriș 2006, 21).

Taking into account the victim's approach, in some cases investigated in Romania, there was an overwhelmingly violent characteristic of both the aggressor who attracts the victim through manipulation and the type of aggressor who is acting immediately. The killer may use his arms and legs as a weapon and when he possesses a firearm, the author takes a considerable distance from the victim. Using a knife or sharpened objects, hitting it repeatedly or twisting a knife into the wound is a sign of a violent altercation (Vasile 2013, 17).

Regarding the characteristics of the lesions, the impacts are directed to the vital areas of the body or focused on a particular area. The victim is depersonalized by disfigurement, the homicide murderer inserts objects into the victim's body, "creatively causes pain" and internal lesions are detected without external bleeding (Vasile, Tandin and Ștefan 2014, 82). At the crime scene, screening for misleading investigators, rearranging the furniture and the room where they penetrated, surrounded by the clutter of objects, is commonplace. The chronology of the events described by the killer in the hearings does not correspond to the scene of the crime. As for the behavior of the author, it moves from anger to calm in a second, stops the pain, letting the victim agonize, returns, consumes food and alcohol at the scene, defecates/urges on/near the corpse, kills the animals that "witness" the crime, sits above the body as a gesture of supremacy, uses multiple methods of inducing pain, spends a lot of time with the victim during its agonization and possibly post-mortem, and participates in the reconstruction of the facts, sometimes being present even at the victim's funeral.

\section{Conclusions}

Without trying to give a definitive judgment on the issue, I believe that, for the time being, the profiling investigation in Romania, is on the rise to gain a well-established, efficient and undisputable investigation place with extrajudicial character. Using this method, acts of unknown author's homicide could be resolved more quickly, identifying and capturing the perpetrator, allowing for a comparative assessment of the criminal profile made prior to the suspect's detention and after his arrest. Starting from the social risk presented by the structures with the behaviors similar to those of the criminals, preventive actions can be organized by reducing the possibilities of manifesting the criminal tendencies, both through the creation of crimino-inhibiting mechanisms and as a result of information actions of possible victims in order to avoid encouraging victimizing situations. The attempts to portray and classify offenders are important both theoretically and practically. Theoretically, it helps to elaborate some explanatory models on how to structure the personality of criminals and at the same time, to highlight some aspects regarding the evolution of such structures in time. From the practical point of view, it helps both on the line of organizing preventive social actions, as well as on the development of social recovery and reintegration programs.

In the cases of murders committed by Romanian authors, it is noted the existence of profound injuries, which target the vital areas specific to the perpetrator who consumed alcoholic beverages or who had a personal connection with his victim, a link with negative feelings like jealousy, abandonment, fear of separation, and so forth. In cases investigated on Romanian territory, the spontaneous conflict becomes an outdated expression that does not provide enough details about the victim-author relationship. The research indicates that behind the hits and the lesions, there are strong motivations about the frustration of the author for whom he has not identified optimal ways of satisfaction. In most cases of murder committed on our territory, the lack of burglary, trampling, or destruction behavior confirms the presence of a criminal who is familiar with his victim. The crime weapon, whether the author carries it with the intention of killing, whether it is within its reach and is used impulsively to commit the act, is abandoned at the scene in most cases or thrown near the criminal field, too few are the ones that keep the murder weapon on them. 
Another finding refers to the relationship between the victim and the offender. The more the relationship between the author and the victim is farther, the more the killer's tendency to physically move away from the crime scene by hiding or leaving the city. If the relationship between the two people is closer, the author of the crime in our country remains closer to the crime scene or even he is the one who calls and announces the authorities.

\section{References}

Budăi, Remus, Gavriş Radu. 2006. Ghidul anchetatorului de omoruri (Guide to the Murder Investigator). Pitești: Argessis Print Publisher.

Butoi Badea, Tudorel, Butoi Ioana Teodora and Butoi Alexandru. 2011. Psihologie judiciară-Victimologie (Judicial psychology-Victimology). Bucharest: Solaris Print Publisher.

Cartwright, Duncan. 2010. Minți criminale-Psihanaliza violenței şi crime (Psychoanalysis, Violence and Rage-Type Murder. Murdering Minds). Bucharest: Trei Publisher.

Crețu, Romeo Zeneo. 2010. Amprenta Comportamentală și evaluarea personalității (Behavioral Mark and Personality Assessment). Iași: Polirom Publisher.

Ionescu, George. 1997. Tulburările personalității (Personality Disorders). Bucharest: Asklepios Publisher.

Lăpăduși, Vasile and Iancu Ștefan. 2004. Investigarea criminalistică a locului faptei (Forensic Investigation of the Crime Scene). Bucharest: Luceafărul Publisher.

Mitrofan, Nicolae, Zdrenghea Voicu and Butoi Tudorel. 1992. Psihologie Judiciară (Judicial Psychology). Bucharest: Casa de Editură şi Presă „Şansa” Publisher.

Paraschiv, Gavril, Paraschiv Daniel-Ștefan and Paraschiv Elena. 2014. Criminologie-Evoluția cercetărilor privind cauzalitatea și prevenirea infracțiunilor (Criminology-Evolution of Research on Causality and Crime Prevention). Bucharest: Pro Universitaria Publisher.

Raine, Adrian. 2014. The Anatomy of Violence. The Biological Roots of Crime. United States of America: Vintage Books Publisher.

Tandin, Traian, Ștefan Cristian Eduard and Țupulan Marin Claudiu. 2014. Discipolii crimei pe mapamond (The Murderers of the Globe). Craiova: Sitech Publisher.

Turvey, Brent. 2011. Criminal Profiling: An Introduction to Behavioral Evidence Analysis, $4^{\text {th }}$ Edition. London: Elsevier Science Publisher.

Vasile, Viorel, Tandin Traian and Ștefan Cristian-Eduard. 2014. De la dispariție la crimă-Cazuri judiciare celebre (From to Disappearance to Murder. Famous Court Cases). Bucharest: Ministry of Internal Affairs Publisher.

Vasile, Viorel. 2013. Investigarea şi cercetarea infracţiunilor îndreptate împotriva vieţii, integrităţii corporale şi sănătăţii persoanei (Investigation of the Crimes against the Life, Body Integrity and the Health of the Person). Bucharest: Ministry of Internal Affairs Publisher..

Yablonsky Lewis. 1990. Criminology, Crime and Criminality. New York: Harper Collins Publishers. 